\title{
ICT green alignment: towards a new generation managerial model based on green IT and corporate social responsibility
}

\author{
Rachid Hba* and Abdellah El Manouar \\ ENSIAS Engineering School, Mohammed V University, Agdal Rabat, Morocco
}

Received: 02-April-2018; Revised: 10-May-2018; Accepted: 15-May-2018

(C)2018 ACCENTS

\begin{abstract}
Talking about sustainable development $(S D)$ in the context of information and communication technology (ICT) management invites us to move forward in a new research area that offers a theoretical framework to integrate the new concepts of social responsibility and environmental companies in the development and implementation of the management strategy. The current context of ICT alignment is characterized by strong environmental and societal incentives and constraints to reduce carbon footprint. Companies must therefore reorient their ICT alignment strategies towards a new sustainable mode to maintain the performance of innovation, transformation and differentiation flows. This perspective opens up a new field of research, which takes into account the interactions with the stakeholders, as well as a better of the technology, the economic and the social adjustment. In this article, we present our new "ICT Green Alignment" model as a next generation framework for ICT management. Our model has been conceptualized using a green IT and corporate social responsibility (CSR) approach, with the aim of helping managers in the process of ICT alignment with business strategy and sustainability. This framework provides a theoretical tool for the design of renewed managerial strategies for SD. In order to approve the validity and applicability of our model, the framework has been tested on the basis of a real case study of a telecom operator.
\end{abstract}

Keywords

Information and communication technology, Green IT, Corporate social responsibility, Sustainable development, ICT management, Alignment.

\section{Introduction}

Strategic alignment expresses the idea of establishing and following a cape [1]. It applies to two elements in companies: the company strategy and the ICT strategy. The strategic alignment of ICT aims to bring the ICT strategy into line with the company's strategy and to plan in a multi-year perspective. Strategic alignment of ICT involves two necessary conditions:

- Understanding and integration of the company's strategy of the IT function as a whole (structures, organizations and tools)

- Taking account of ICT constraints and opportunities in the company's strategy.

Figure 1 shows the integration that must be made between the IT strategy and the support function on one side; on the other side, it specifies the need to align the business strategy with the different levels of the overall IT strategy.

\footnotetext{
*Author for correspondence
}

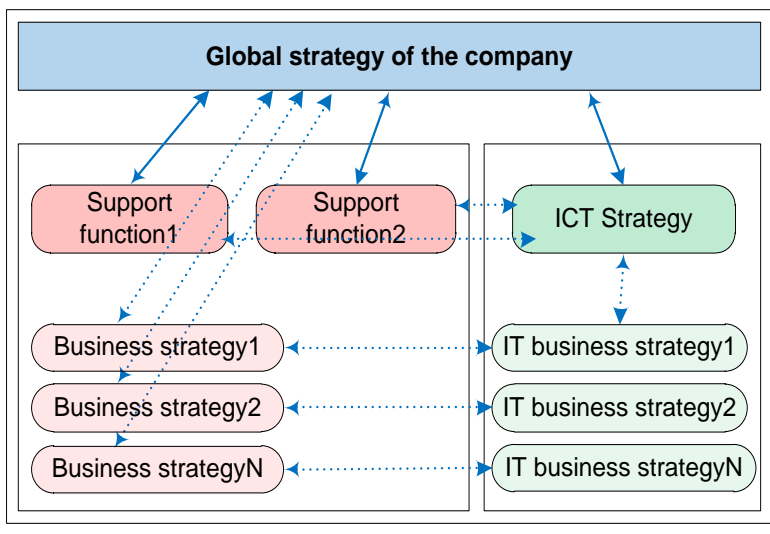

Figure 1 IT functions and business alignment

In addition, the strategic alignment of ICT is needed in the enterprise because it provides a framework for strategy formulation as well as its implementation. According to [2], the company can seek and obtain higher performance as well as a competitive advantage, by setting up a combined business and ICT alignment plan through direct mapping of the ICT strategy with one or more business strategies. 
This alignment plan requires the ability to acquire and deploy resources that are consistent with the organization's competitive needs [3]. Therefore, the alignment process requires sharing information about organizational goals and objectives at different levels and within different units of the organizational hierarchy. The company is constantly invited to gather and reconfigure internal and external skills to adapt to ever-changing business environments.

For decades, the strategic alignment of ICT with the company's global business strategy has been the subject of extensive research. Indeed, this field is a vast subject far from being exhausted, as ICT is no longer just a way of streamlining the flow of production. Business activities and processes are based on increased use of ICT [1], resulting in new strategies and new competitive advantages. However, despite the many researches in this field, the impact of the strategic alignment of ICT on economic, social and environmental performance remains unexplored, according to the results reported in the literature and which remain mixed. In this paper, we will advance our understanding of mixed results in research on the ICT alignment through the proposal of a new alignment model based on green IT and CSR.

The strategic alignment of ICT is the basic process of restructuring the IT organization and processes and the production system so that they are in perfect harmony with the overall strategy that has been put in place by the managers of the company. ICT alignment therefore also results from the joint coherence between strategic choices (strategic alignment), organizational design (structural alignment) and the use of ICT (technological alignment). This definition has its origins in the theory of contingency, which states that the performance of the enterprise is the result of the congruence between one or more factors. According to [4], the strategic alignment model assumes that the ICT strategy must be consistent with the overall business strategy in order to achieve improved performance.

\subsection{Literature review: strategic alignment model} (SAM) positioning

As noted in the previous section, models derived from contingency theory are based on processes that provide a framework for exploiting theories and research findings on the interrelationships and characteristics of organizations [4]. In this section, we present only the few ICT alignment models that have been particularly influential. We focus on the research that emerged in the early 1990s from North America and Europe. Many studies have subsequently used the concepts of these models. Research conducted prior to the 1990s was the first attempt to harness the strategic power of ICT [5]. This work has argued that a revolutionary change involving investment in ICT can yield consistent benefits as long as the key elements of strategy, technology, structure, management processes and individuals. In particular, researchers focused on the position of the ICT alignment strategy and its implementation, which is seen as a vector for strategic external integration [4] and also for functional integration [5] by physically decompartmentalizing the company from its environment.

In 1993, Henderson and Venkatraman professors at the MIT Sloan School of Management in Boston found that there was a consequent lack of fundamental frameworks to understand the potential of ICT for organizations in the future [6], despite the change in the role that ICT can play, moving from a supporting role to a strategic one. The strategic alignment model (SAM) was therefore constructed by these authors in order to overcome this lack of modeling the new strategic area of ICT that emerged at the time. Their research focuses on the impact of the emergence of ICT on sources of competitive advantage and the organizational interrelationships between strategic and technology planning of these ICT. The concept of alignment addressed by these two authors is based on two assumptions:

- Financial and economic performance is directly determined by an organization's ability to create an adjustment between the organization's position and the adoption of an appropriate administrative structure to support its execution.

- The cited adjustment is characterized by dynamism and the process of alignment is in full change and continuous adaptation. To achieve this dynamic capacity, there must be organizational arrangements to put in place the appropriate technologies to create differentiation in the activities of the organization.

The concept of ICT alignment according to the SAM model is articulated and aims to find coherence around four fundamental areas of management [4]:

- Business strategy: defines the company's positioning in its market (product / market), its distinctive competencies and its business.

- ICT strategy: corresponding to the choice of ICT and the governance mechanism. 
- Infrastructure and organizational processes: are interested in the design of organizational structures: administrative structure, definition of business processes.

- ICT infrastructure and processes: covers the portfolio of applications, management and technical skills related to ICT, infrastructure, technological development processes.

From these four dimensions-domains, the strategic alignment model SAM proposes to ensure the coherence of strategic choices according to two main axes.

Figure 2 shows the alignment axes for the four dimensions of the SAM model, two main axes which are strategic adjustment and functional integration in addition to a third secondary axis for alignment of opposite dimensions.

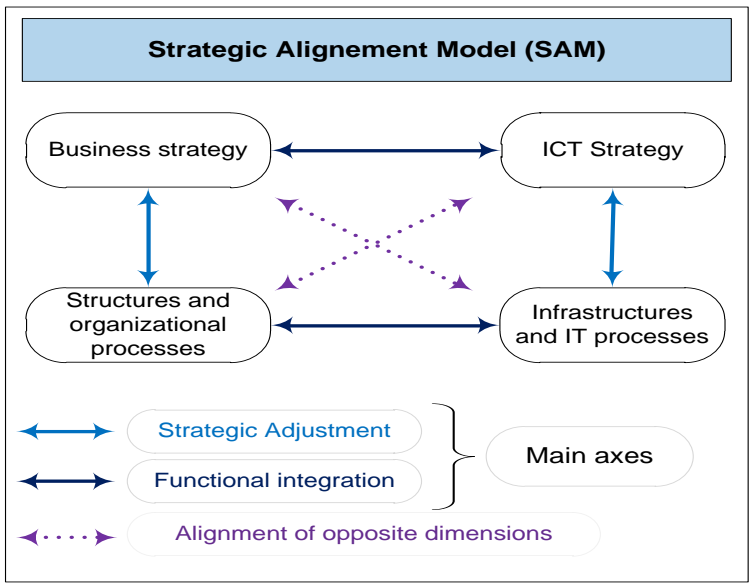

Figure 2 "Strategic alignment model"-SAM

\section{Strategic adjustment}

It is interested in the alignment between external domains and internal domains. Indeed, there must be coherence between the company's strategy and the organizational structure on the one hand, and coherence between the IT strategy and the ICT implemented on the other. This adjustment identifies the need to manage the choices that position the company on an external market and decide how best to structure the company's internal arrangements to execute this market positioning strategy. The choices that position the company in a marketplace are referred to a business strategy and those that determine the internal structure of the business as organizational organizations and processes.

\section{Functional integration}

It corresponds to the integration of the business 139 domain and the technological field. It represents the horizontal relationship, which is an extension of the notion of strategic adjustment to the functional area of the strategic alignment framework. As business strategies change, IT strategies and processes must also keep pace and correspondingly, the infrastructure and processes need to keep pace with the change in business or ICT.

The relevance of the model is justified through these two fundamental axes of strategic management, which are: strategic adjustment and functional integration. The first axis refers to the adjustment that must be made between the external positioning of the organization and its internal commitment [4]. To position oneself, the company must define the scope of the adoption of the ICT that it must put in place, the systemic competences that it must have, and a governance of these ICT. At the same time, it must also make choices for its internal agreement concerning the definition of ICT architectures, implementation of processes and IT skills. The second fundamental axis of the model are aimed at both the strategic integration and the operational integration of the business and IT domains.

The alignment of the opposite dimensions describes:

- Alignment between business strategy and IT infrastructure and processes represents a traditional linking view that requires the specification of work processes, roles, and authority structures to report how products and services will affect the business strategy. That is, the business strategy must be broken down into a work process to define the requirements of IT infrastructure and processes.

- Alignment between IT strategy and organizational structures and processes reflects a vision of automating the work environment. This represents the potential of ICT to change organizational processes. This vision focuses on the potential value of ICT and how IT infrastructure and processes provide a service organization to support that potential.

The SAM model offers four dominant perspectives of alignment. These perspectives were conceived on the basis of the two aforementioned axes and the relations between the four domains which are necessarily multivariate relations:

\section{Business strategy}

The business strategy is the first dimension of the SAM model, in which the company competes and is concerned with strategic decisions. 
The business strategy consists of three components shown in Figure 3.

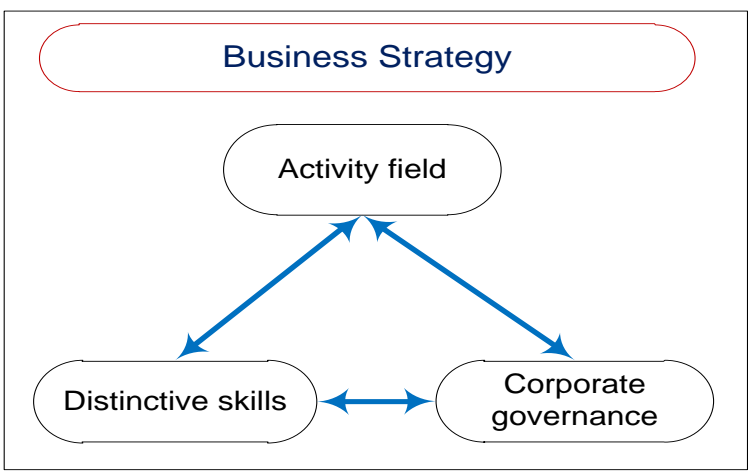

Figure 3 SAM model-perspectives 1

Activity field: Includes markets, products, services, customer groups and sites where a company competes and potential competitors that affect the business environment.

Distinctive skills: Critical success factors and core competencies that provide a business with a potential competitive advantage. This includes the brand (type of product manufactured by a particular company), research, manufacturing and product development, cost and price structure, and sales and distribution channels.

Corporate governance: How companies establish the relationship between management, shareholders and the board of directors. The inclusion of the company is also influenced by government regulation and how the company manages its relationships and alliances with strategic partners.

\section{Infrastructure and organizational processes}

This dimension is activity-centric and looks for the attributes that contribute to the competitive advantage and roles and responsibilities in the organization, as well as the business processes that support the company's ability to execute business strategies, through the development of the necessary business skills.

Figure 4 shows the three components of this SAM perspective.

Administrative infrastructure: How the company organizes its activities (central, matrix, horizontal, vertical, geography, federal and functional).
Process: How the business activities of the company (the work done by the employees) work. Key issues include value-added activities and process improvement.

Skills: Human resource considerations such as hiring, motivating, training, educating and cultivating.

\section{IT Strategy}

The IT strategy shown in Figure 5 helps define the vision by which, the demand for ICT and the organization will be supported by the company.

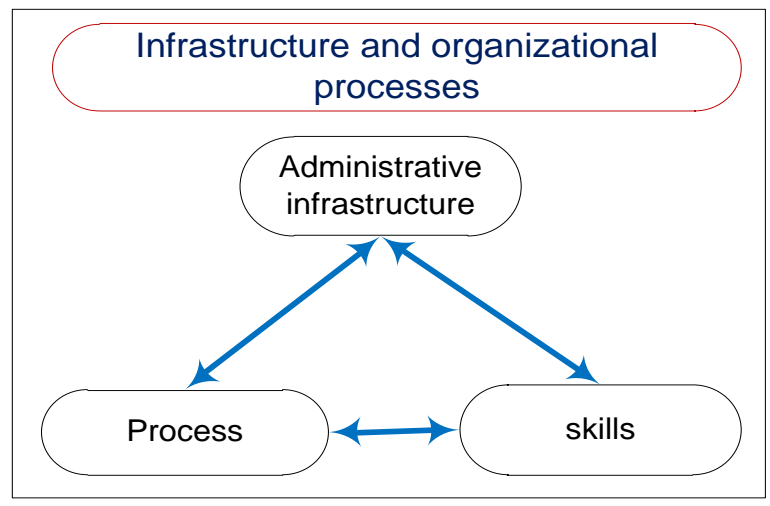

Figure 4 SAM model-perspective 2

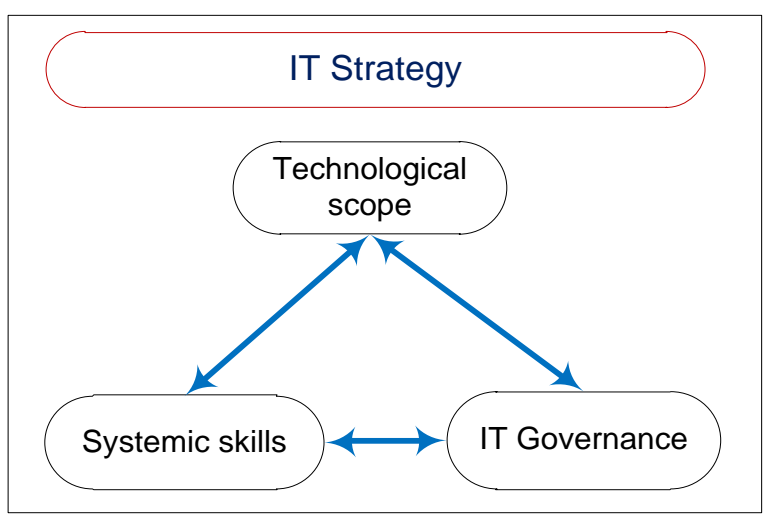

Figure 5 SAM model-Perspective 3

The IT strategy of the SAM model refers to the company's position in the ICT market. This strategy consists of the following components:

Technological Scope: The important applications and ICT put in place.

Systemic Skills: These capabilities (for example, access to information that is important to the creation/execution of a company's strategy) that distinguish IT services. 
IT Governance: How to manage resources, risk, conflict resolution and ICT responsibility are shared among business partners, ICT management and service providers. Project selection and prioritization issues are included here.

\section{IT Infrastructure and process}

According to the model, Figure 6 shows how the IT domain can effectively manage and operate the IT infrastructure and process.

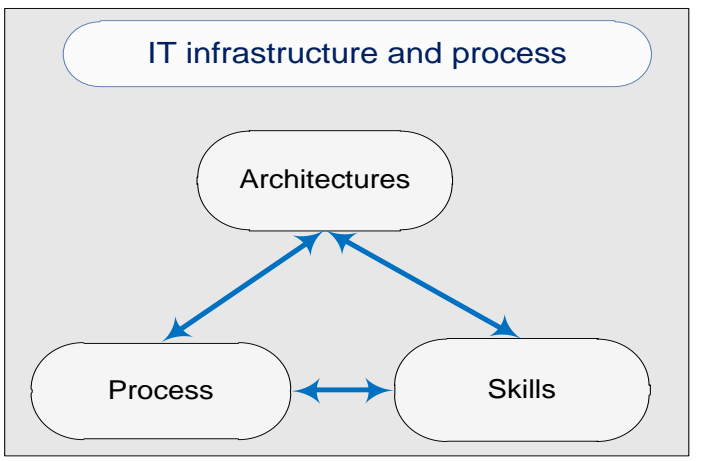

Figure 6 SAM model-perspective 4

This dimension consists of the three following components:

Architectures: Technology priorities, policies, and choices that enable applications, software, networking, hardware, and data management to be integrated into a consistent platform.

Process: Practices and activities to develop and maintain applications.

Skills: Human resource considerations in IT terms, such as how to hire, motivate, train or educate and culturally.

\subsection{Positioning synthesis}

We have presented the characteristics of the SAM approach of ICT alignment that studied in this paper are as follows. This is a summary that will help us in the development of the new alignment model:

- A reference for the majority of academic publications on the subject.

- This model is built in two dimensions: strategic adjustment and functional integration.

- The challenge is to make ICT an asset in the service of the company's business strategy.

- According to the model the notion of alignment is complex and can go beyond the link between ICT and business strategy.
- Identifies the external perspective of ICT (IT strategy) from its internal development (IT infrastructure and process).

- Provides a global definition of strategic alignment.

- Uses balanced scorecards.

- Causal approach that allows the study of phenomena related to alignment (influence on the performance of companies).

- The SAM model does not provide a construction or an instrument for measuring and evaluating alignment.

- The SAM model does not take into account the sustainability aspect (CSR and Green IT) in the ICT alignment approach.

\section{Materials and methods}

This section provides information on our new concept of ICT strategic alignment in theory, and addresses three important aspects within the ICT strategic alignment in business. The first aspect is to recall and clarify the working hypotheses and the problems of ICT strategic alignment. The second aspect proposes a description of the new conceptual model "ICT Green Alignment". At the third point we will try to apply the new model for a case study, to test it empirically using the data of a telecom operator. The empirical data will be presented and analyzed in the next section.

\subsection{Working hypothesis and problem}

The implementation of Green IT practices and the CSR strategy can have the capacity to contribute to the achievement of SD objectives through the implementation of eco-responsible ICT alignment initiatives. As stated in the SAM Model synthesis, the alignment approach was not easy to conduct, because its adoption in a holistic way involves multiple stakeholders, forcing policy makers to adopt a more dynamic and crosscutting approach. In addition, it is necessary to design strategies in a sustainable way and in line with business objectives.

We therefore need an ICT alignment model that provides an effective Framework for integrating the concepts of CSR objectives and Green IT. The process of ICT alignment involves multiple stakeholders in an increasingly complex system, making it more difficult to define a framework that can contribute to the enrichment of managerial models. The ICT green alignment model is based on Green IT and CSR, which improves the lifespan of relationships with all stakeholders [7, 8]. It also ensures the sustainability of resources $[9,10]$ and constitutes an effective managerial framework. 


\subsection{New proposed model}

In the following of this paper we will try to fill the gap in the literature on the subject of the strategic alignment of ICT according to the CSR approach and green IT. We have provided a new alignment model that can be used to describe strategic alignment strategies redesigned according to a green IT and CSR-based SD strategy. To do this, we have adopted a holistic approach that extends the concept of "Balanced Scorecard", developed by Kaplan and Norton [11] in 1992. This concept was based on four perspectives: customer, finance, business processes, growth and learning.

We have proposed to modify this concept to take into account the integrated strategy of Green IT and CSR that we presented. This approach is proving more effective, which, thanks to the practices of green IT and CSR, makes it possible to improve the ICT alignment process by playing a central role in the creation of value towards all the stakeholders.

We introduced the "ICT green alignment" model that we have designed on the following three pillars: ICT strategy, business strategy, societal and environmental strategy. These three pillars are aligned according to the Green IT and CSR approach:

In the Figure 7, the ICT strategy is aligns with the concept of green IT and CSR to achieve the goals of SD and technology efficiency (carbon footprint) and value creation. This strategy encourages the creation of new forms of management based on SD, which requires the implementation of the societal and environmental strategy, which in turn makes it possible to create differentiation and to improve technology and organizational practices in an innovative way.

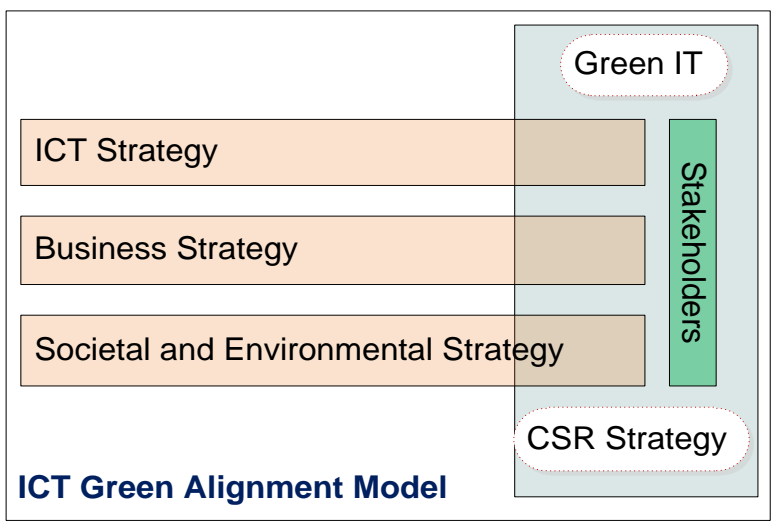

Figure 7 "ICT green alignment" model

\subsubsection{ICT strategy}

The concept of green IT should be integrated into the theoretical framework of the ICT strategy to facilitate the link between environmental IT practices and the strategic context of the enterprise. The ICT strategy articulates how the application of IT is expected to meet the organization's requirements by providing efficient IT processes and services to the business, supporting business objectives, and providing value. The ICT strategy must therefore refer to the specific competitive environment of the company and its business objectives.

The ICT strategy takes into account the costs, risks and opportunities of currently available and future ICT and needs to assess their potential business impact. Competitive advantage must be considered from two dimensions: the internal dimension, where ICT can enable profitable business processes, and the external dimension, where ICT can be used to deliver unique customer value [12]. The ICT organization should be efficient and effective in providing internal and standardized technology solutions while developing distinctive solutions focused on the external business environment.

We have proposed a definition of the ICT strategy that focuses on the Green IT and CSR strategy. This concept is supposed to allow a holistic IT management taking into account the strategic objectives and the environmental aspects. On the one hand, this strategy ensures that IT systems and applications meet the demands of the business. This is aimed at optimizing the IT architecture, taking into account efficiency and functionality.

2.2.2Business strategy

The business value and competitive advantage are created by effective provisioning of services, superior IT services that provide differentiation and technological innovations that create IT-based business opportunities. On the other hand, the ICT strategy is aligned with the SD strategy through the concept of green IT and CSR, which improves the eco-efficiency of the IT infrastructure. The reduction targets for ICT-related emissions are determined by the objectives of the enterprise SD strategy. In this way, Green IT support the sustainability of this strategy by facilitating eco-efficiency and competitive differentiation.

In addition, green IT can create opportunities for environmental, technological innovations, which can change current business practices. 
Exploiting all the competitive potential requires the strategic alignment of the Green IT strategy and the CSR strategy. At this point, we have decided to refer to generic choice-based environmental competition strategies, which are closely aligned with our understanding of business strategy, value creation and the competitive advantage of environmental initiatives.

2.2.3Societal and environmental strategy

Our model is based on the logic and basic procedures of the SAM model, which joins our distinction between internal and external sources of competitive advantage. The new generation model [13], in its "ICT green alignment" dimension, is conceptualized in order to identify the sources of competitive advantage and thus align green environmental technologies and competitive environmental strategies geared towards outside. This dimension allows the realization of the strategic adjustment that eliminates the current constraints of the strict internal perspective of Green IT practices and connects the Green IT to the external strategic perspective, integrating the customer and stakeholder aspects and revealing sources of competitive advantage for the product.

Sustainability goals can only be achieved if the strategies are implemented on the basis of an appropriate IT and organizational infrastructure, which forms the basis of low-impact business processes. The process of functional integration between Green IT and environmental sustainability takes into account the impact of green IT of the sustainability strategy and vice versa, indicating how green IT can benefit from the competitive sustainability strategy and how a SD-oriented infrastructure can increase the sustainability of business operations.

We have proposed a new balanced scorecard approach to implement the "ICT green alignment" dimensions. Our approach integrates environmental and societal strategy into the strategic ICT alignment process. The power of the model we propose is reflected in three fundamental perspectives of alignment:

In Figure 8, we present the three perspectives of our framework; the first perspective refers to the alignment that must be made between the ICT strategy and the business strategy. In Figure 8, we present the three perspectives of our framework; the first perspective refers to the alignment that must be made between the ICT strategy and the business strategy. To position oneself, the company must define the scope and objectives of the ICTs it must implement to support business objectives and develop business skills and knowledge. The company also needs to build infrastructure and implement appropriate IT processes that can optimize both the execution of ICTs and the optimization of business processes.

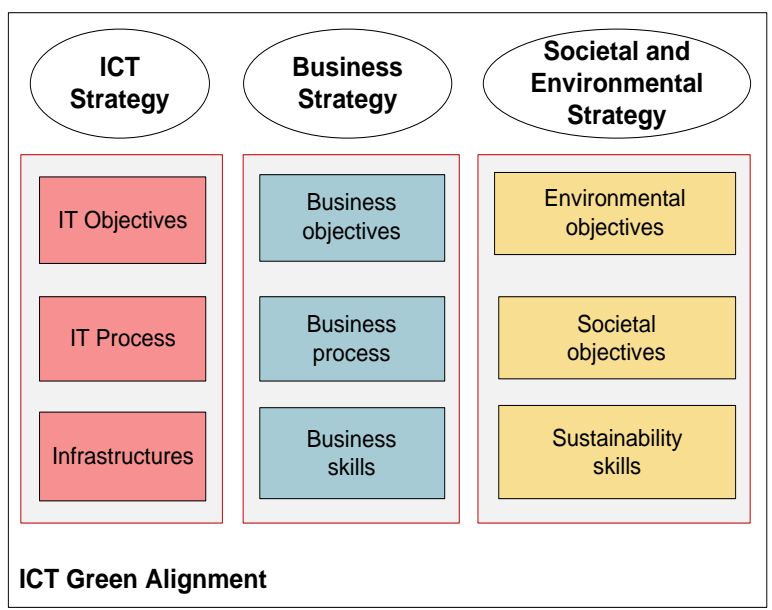

Figure 8 "ICT green alignment" framework

The second perspective aims at aligning the ICT strategy with the societal and environmental strategy. The ICT strategy aims to achieve environmental and societal goals as well as to develop know-how based on sustainability.

The third perspective of the model is the alignment between the business strategy and the societal and environmental strategy.

\subsection{Evaluation and application of the model}

The theoretical "ICT green alignment" model proposed in this work has allowed us to provide a useful framework for examining the potential of implementing green IT and CSR initiatives for ICT management. The proposed model is the first attempt to synthesize a theoretical foundation that helps companies to assess their potential for green technology initiatives through strategic ICT alignment processes.

This paragraph will be dedicated to the application of our model on a case study of a telecom operator, in order to empirically examine the proposed model and allow its validation. For confidentiality reasons, some parts of the case study have been adapted. The documents used are not all public, so work has been done to filter the restricted information. Firstly, we 
carried out a qualitative empirical study aimed at comparing in general terms the hypotheses of the model with the organizational realities of the firm selected for the case study. The goal is to arrive at the formulation of testable hypotheses.

The group is committed to implementing the principles of the global compact relating to the societal component through the establishment of a set of more than 58 societal indicators. The operator shall apply and measure each indicator according to the practices and strategy stipulated for each principle. Table 1 describes the set of practices put in place by the operator for the societal objectives, expected by the principles of the global compact.

The operator is also committed to implementing the principles of the global compact in the environmental field through the implementation of a set of 23 environmental indicators.

Table 2 shows the practices established for this purpose:

Table 1 Case study: societal strategy

\begin{tabular}{|c|c|}
\hline Human rights & Practice \\
\hline $\begin{array}{l}\text { Principle 1: Businesses are encouraged to promote and } \\
\text { respect the protection of international human rights } \\
\text { law. }\end{array}$ & $\begin{array}{l}\text {-The operator promotes access to culture for all and cultural diversity } \\
\text {-The operator supports the growing demand for digital uses } \\
\text {-The operator facilitates access to communication tools to as many } \\
\text { people as possible } \\
\text {-The operator supports the education and training of young people }\end{array}$ \\
\hline $\begin{array}{l}\text { Principle 2: Companies are encouraged to ensure that } \\
\text { they are not complicit in human rights abuses. }\end{array}$ & $\begin{array}{l}\text {-The operator is involved with civil society to fight against social } \\
\text { exclusion } \\
\text {-The operator associates its partners with its principles of ethics and } \\
\text { respect for human rights. } \\
\text {-The operator is vigilant in terms of risks related to the uses of digital } \\
\text {-The operator protects the personal data of its customers and } \\
\text { employees }\end{array}$ \\
\hline Work rights & Practice \\
\hline $\begin{array}{l}\text { Principle 3: Businesses are invited to respect freedom } \\
\text { of association and to recognize the right to bargain } \\
\text { collectively }\end{array}$ & \multirow{4}{*}{$\begin{array}{l}\text {-The operator imposes on his partners respect for labor law } \\
\text {-The operator promotes equal opportunities and practices equal } \\
\text { treatment of his employees without any form of discrimination } \\
\text {-The operator respects the provisions of the national labor code } \\
\text {-The operator recognizes freedom of association and the right to } \\
\text { collective bargaining }\end{array}$} \\
\hline $\begin{array}{l}\text { Principle 4: The elimination of all forms of forced or } \\
\text { compulsory labor }\end{array}$ & \\
\hline Principle 5: The effective abolition of child labor & \\
\hline $\begin{array}{l}\text { Principle 6: Elimination of discrimination in respect of } \\
\text { employment and occupation }\end{array}$ & \\
\hline
\end{tabular}

Table 2 Case study: environmental strategy

\begin{tabular}{ll}
\hline Environment & Practice \\
\hline $\begin{array}{l}\text { Principle 7: Businesses are encouraged to apply the } \\
\text { precautionary approach to environmental issues }\end{array}$ & $\begin{array}{l}\text { The operator defends respect for the environment inside and outside } \\
\text { the company }\end{array}$ \\
& $\begin{array}{l}\text {-The operator takes advantage of technological innovations to } \\
\text { minimize the environmental impact of its activities and contribute to } \\
\text { the preservation of the environment }\end{array}$
\end{tabular}

\footnotetext{
Principle 8: Businesses are encouraged to undertake initiatives to promote greater environmental responsibility

Principle 9: Businesses are encouraged to promote the development and diffusion of environmentally friendly technologies
}

On the economic side, the operator is committed to applying the tenth principle of the global compact for ethics and the fight against corruption.
Table 3 is dedicated to the business strategy and sets out the approach adopted by the telecom operator in order to reach the tenth principle: 
Table 3 Case study: business strategy

\section{Ethics and the fight Practice} against corruption

Principle 10: Businesses -The operators of the operator should work against are required to respect the corruption in all its principles of its code of ethics forms, including -The operator acts against extortion and bribery corruption in all its forms

The operator continues to adopt green IT practices in its ICT strategy as specified in Table 4:

Table 4 Case study: ICT strategy

\begin{tabular}{|c|c|}
\hline IT Objectives & Practice \\
\hline $\begin{array}{l}\text { ICT optimization and } \\
\text { sustainability practices }\end{array}$ & $\begin{array}{l}\text {-Cost reduction } \\
\text {-Adoption of Green IT } \\
\text {-Green IT / CSR research and } \\
\text { development }\end{array}$ \\
\hline $\begin{array}{l}\text { ICT security and } \\
\text { availability practices }\end{array}$ & $\begin{array}{l}\text {-IT services security } \\
\text {-Continuity of IT services }\end{array}$ \\
\hline IT Processes & Practice \\
\hline $\begin{array}{l}\text { Practices for continuous } \\
\text { improvement of IT } \\
\text { processes }\end{array}$ & $\begin{array}{l}\text {-Optimization of IT processes } \\
\text {-Flexibility and scalability } \\
\text {-Agility and transversality }\end{array}$ \\
\hline Infrastructures & Practice \\
\hline $\begin{array}{l}\text { IT Infrastructure } \\
\text { management practices }\end{array}$ & $\begin{array}{l}\text {-Optimization of IT } \\
\text { infrastructures } \\
\text {-High availability and security }\end{array}$ \\
\hline
\end{tabular}

\section{Results}

This section presented the results of the case study has been conducted with a local telecom operator.
We have presented the results obtained by the experimentation of our new management model. These results allow us to qualify the mode of ICT alignment adopted by the telecom operator. At the same time the application of different axes has been checked and developed in our model and compare them in each strategy set up by the operator. For each strategy, a set of indicators has been defined and evaluated on the basis of two main contributions: firstly, the annual report of CSR and the plan for implementing the ten principles of the global compact within the telecom operator.

Tables 5, 6 and 7 present the result of evaluation of each dimension of our model and which are; business strategy, ICT strategy and societal and environmental strategy.

Table 5 shows that the IT strategy of the operator is $60 \%$ consistent with our model, while $40 \%$ of the indicators are in partial application.

In Table 6 the experiment of the axis relating to the business strategy shows the application to $95 \%$ of the indicators of our model, a single indicator is in progress

For the last axis, Table 7 shows that the operator is in the progressive application of the environmental and societal strategy.

Table 5 Evaluation of the ICT strategy

\begin{tabular}{|c|c|c|c|c|c|c|}
\hline \multirow[t]{2}{*}{ Strategy } & \multirow[t]{2}{*}{$\begin{array}{l}\text { Adopted } \\
\text { (Yes/No) }\end{array}$} & \multirow[t]{2}{*}{ Practices } & \multirow[t]{2}{*}{$\begin{array}{l}\text { Applied } \\
\text { (Yes/No) }\end{array}$} & \multirow[t]{2}{*}{ Indicators } & \multicolumn{2}{|c|}{$\begin{array}{l}\text { Level of monitoring } \\
\text { and applicability }\end{array}$} \\
\hline & & & & & Yes No & Partial \\
\hline \multirow{5}{*}{ IT Objectives } & \multirow{5}{*}{ Yes } & \multirow{3}{*}{$\begin{array}{l}\text { ICT optimization and } \\
\text { sustainability } \\
\text { practices }\end{array}$} & \multirow{3}{*}{ Yes } & Cost reduction & $\mathrm{X}$ & \\
\hline & & & & Adoption of Green IT & & $\mathrm{X}$ \\
\hline & & & & $\begin{array}{l}\text { Green IT / CSR research and } \\
\text { development }\end{array}$ & & $\mathrm{X}$ \\
\hline & & \multirow{2}{*}{$\begin{array}{l}\text { ICT security and } \\
\text { availability practices }\end{array}$} & \multirow[t]{2}{*}{ Yes } & IT services security & $\mathrm{X}$ & \\
\hline & & & & Continuity of IT services & $\mathrm{X}$ & \\
\hline \multirow[t]{3}{*}{ IT Process } & \multirow[t]{3}{*}{ Yes } & \multirow{3}{*}{$\begin{array}{l}\text { Practices for } \\
\text { continuous } \\
\begin{array}{l}\text { improvement of IT } \\
\text { processes }\end{array}\end{array}$} & \multirow[t]{3}{*}{ Yes } & Optimization of IT processes & $\mathrm{X}$ & \\
\hline & & & & Flexibility and scalability & $\mathrm{X}$ & \\
\hline & & & & Agility and transversality & & $X$ \\
\hline \multirow[t]{2}{*}{ Infrastructures } & \multirow[t]{2}{*}{ Yes } & \multirow{2}{*}{$\begin{array}{l}\text { IT Infrastructure } \\
\text { Management } \\
\text { Practices }\end{array}$} & \multirow[t]{2}{*}{ Yes } & $\begin{array}{l}\text { Optimization } \\
\text { infrastructures }\end{array}$ & & $\mathrm{X}$ \\
\hline & & & & High availability and security & $\mathrm{X}$ & \\
\hline
\end{tabular}


Hba and Manouar

Table 6 Evaluation of the business strategy

\begin{tabular}{|c|c|c|c|c|c|c|c|}
\hline \multirow[t]{2}{*}{ Strategy } & \multirow[t]{2}{*}{$\begin{array}{l}\text { Adopted } \\
\text { (Yes/No) }\end{array}$} & \multirow[t]{2}{*}{ Practices } & \multirow[t]{2}{*}{$\begin{array}{c}\text { Applied } \\
\text { (Yes/No) }\end{array}$} & \multirow[t]{2}{*}{ Indicators } & \multicolumn{3}{|c|}{$\begin{array}{c}\text { Level of monitoring and } \\
\text { applicability }\end{array}$} \\
\hline & & & & & Yes & No & Partial \\
\hline \multirow{8}{*}{$\begin{array}{l}\text { Business } \\
\text { objectives }\end{array}$} & \multirow[t]{8}{*}{ Yes } & Strategic & \multirow[t]{4}{*}{ Yes } & Operational effectiveness & $\mathrm{X}$ & & \\
\hline & & guidance & & Product Leadership & $\mathrm{X}$ & & \\
\hline & & \multirow[t]{2}{*}{ practices } & & Differentiation of competition & $\mathrm{X}$ & & \\
\hline & & & & Stakeholder satisfaction & $\mathrm{X}$ & & \\
\hline & & Productivity & \multirow[t]{4}{*}{ Yes } & Reduce time and costs & $\mathrm{X}$ & & \\
\hline & & Improvement & & Improving the quality of & $\mathrm{X}$ & & \\
\hline & & Practices & & financial information & & & \\
\hline & & & & $\begin{array}{l}\text { Application of accounting } \\
\text { measures such as ROI }\end{array}$ & $\mathrm{X}$ & & \\
\hline \multirow{8}{*}{$\begin{array}{l}\text { Business } \\
\text { Process }\end{array}$} & \multirow[t]{8}{*}{ Yes } & Business & \multirow[t]{8}{*}{ Yes } & Standardization of business & $\mathrm{X}$ & & \\
\hline & & Process & & processes & & & \\
\hline & & $\begin{array}{l}\text { Transformati } \\
\text { on Practices }\end{array}$ & & $\begin{array}{l}\text { Shortening the order cycle } \\
\text { and production cycles }\end{array}$ & $\mathrm{X}$ & & \\
\hline & & & & $\begin{array}{l}\text { Automation of commercial } \\
\text { transactions }\end{array}$ & $\mathrm{X}$ & & \\
\hline & & & & $\begin{array}{l}\text { Optimization of operational } \\
\text { processes }\end{array}$ & $X$ & & \\
\hline & & & & Cost reduction & $\mathrm{X}$ & & \\
\hline & & & & Business Process Monitoring & $\mathrm{X}$ & & \\
\hline & & & & Organizational efficiency & $\mathrm{X}$ & & \\
\hline \multirow{3}{*}{$\begin{array}{l}\text { Business } \\
\text { skills }\end{array}$} & \multirow[t]{3}{*}{ Yes } & $\begin{array}{l}\text { Business } \\
\text { Innovation }\end{array}$ & \multirow[t]{3}{*}{ Yes } & $\begin{array}{l}\text { Innovation and economic } \\
\text { intelligence }\end{array}$ & $X$ & & \multirow{3}{*}{$\mathrm{X}$} \\
\hline & & Practices & & Research and development & & & \\
\hline & & & & $\begin{array}{l}\text { Improved business } \\
\text { intelligence }\end{array}$ & $\mathrm{X}$ & & \\
\hline
\end{tabular}

Table 7 Evaluation of the societal and environmental strategy

\begin{tabular}{|c|c|c|c|c|c|c|}
\hline \multirow[t]{2}{*}{ Strategy } & \multirow{2}{*}{$\begin{array}{l}\text { Adopted } \\
\text { (Yes/No) }\end{array}$} & \multirow[t]{2}{*}{ Practices } & \multirow{2}{*}{$\begin{array}{l}\text { Applied } \\
\text { (Yes/No) }\end{array}$} & \multirow[t]{2}{*}{ Indicators } & \multicolumn{2}{|c|}{ Level of monitoring and applicability } \\
\hline & & & & & Yes & Partial \\
\hline \multirow[t]{2}{*}{$\begin{array}{l}\text { Environmental } \\
\text { objectives }\end{array}$} & Yes & $\begin{array}{l}\text { Environmental } \\
\text { Leadership }\end{array}$ & Yes & $\begin{array}{l}\text { Leadership } \\
\text { environmental costs }\end{array}$ & & $\mathrm{X}$ \\
\hline & & Practices & & $\begin{array}{l}\text { Leadership } \\
\text { environmental } \\
\text { compliance }\end{array}$ & & $\mathrm{X}$ \\
\hline $\begin{array}{l}\text { Societal } \\
\text { objectives }\end{array}$ & Yes & $\begin{array}{l}\text { Societal } \\
\text { Leadership } \\
\text { Practices }\end{array}$ & Yes & $\begin{array}{l}\text { Leadership of } \\
\text { compliance with societal } \\
\text { requirements }\end{array}$ & $\mathrm{X}$ & \\
\hline \multirow[t]{2}{*}{$\begin{array}{l}\text { Sustainability } \\
\text { skills }\end{array}$} & Yes & $\begin{array}{l}\text { Innovation } \\
\text { practices in }\end{array}$ & Yes & $\begin{array}{l}\text { Promote ecological } \\
\text { innovations }\end{array}$ & & $\mathrm{X}$ \\
\hline & & terms of SD & & $\begin{array}{l}\begin{array}{l}\text { Develop Green IT } \\
\text { technologies }\end{array} \\
\end{array}$ & & $\mathrm{X}$ \\
\hline
\end{tabular}

\section{Discussion}

As part of this case study, we explored the two internal and external organizational contexts of the operator as well as the technological context according to a principle of data collection in the information systems department and the sustainable development department. These are mainly contexts where the management of CSR and green IT has become explicit. The aim is to evaluate the practices adopted by the managers and compare them with the practices developed within the framework of our model.
In this section an overall review of our case study has been highlighted, in which we can deduce that the case chosen for our study is either a good candidate for adoption of our ICT alignment model. Indeed, environmental and societal practices have been adopted and the motivations of CSR and green IT are applied in the ICT alignment strategy at the threedimensional level. Thus, the chosen indicators confirm the validation test of our "ICT green alignment" model. 


\section{Conclusion}

The "ICT green alignment" model is built on a holistic research approach, which has led us to focus on transversal modes of ICT alignment to better meet the expectations of all stakeholders. Our innovative approach is based on a simple principle that aims to implement basic SD concepts in the ICT alignment process.

The reflection that we conducted is a first step towards a more thorough and approved approach tested on the basis of a real case study, in order to pilot research in the field of ICT management systems according to the concept of SD. In another step we proposed to start from this basic model, to design a new generation ICT alignment repository that is developed on the principles of green IT and CSR.

\section{Acknowledgment}

None.

\section{Conflicts of interest}

The authors have no conflicts of interest to declare.

\section{References}

[1] Chan YE, Reich BH. IT alignment: what have we learned? Journal of Information Technology. 2007; 22(4):297-315.

[2] Porter ME. Towards a dynamic theory of strategy. Strategic Management Journal. 1991; 12(S2):95-117.

[3] Ward J, Griffiths PM, Whitmore P. Strategic planning for information systems. Chichester Wiley; 2002.

[4] Henderson JC, Venkatraman H. Strategic alignment: leveraging information technology for transforming organizations. IBM Systems Journal. 1993; 32(1):47284.

[5] Wang HL, Ghose A. On the foundations of strategic alignment. In proceedings of Australia and New Zealand academy of management conference 2006.

[6] Henderson JC, Venkatraman N. Strategic alignment: a model for organizational transformation through information technology. Transforming Organizations. 1990: 97-117.

[7] Betz F. Managing technological innovation: competitive advantage from change. John Wiley \& Sons; 1998.
[8] Rennings K. Redefining innovation-eco-innovation research and the contribution from ecological economics. Ecological Economics. 2000; 32(2):31932.

[9] Rennings K, Wiggering H. Steps towards indicators of sustainable development: linking economic and ecological concepts. Ecological Economics. 1997; 20(1):25-36.

[10] Bieker T. Sustainability management with the balanced scorecard. Corporate Sustainability: Theoretical Perspectives and Practical Approaches. 2005:121-46.

[11] Kaplan R S and Norton DP. The balanced scorecard: measures that drive performance. Harvard Business Review $1992 . \quad$ https://umei007fall10.wikispaces.com/file/view/Kaplan\%26Nortonbal anced+scorecard.pdf. Accessed 26 March 2018.

[12] Abernathy WJ, Utterback JM. Patterns of industrial innovation. Technology Review. 1978; 80(7):40-7.

[13] Hba R, Bakkas A, Manouar AE, Idrissi MA. Ecostrategy: towards a new generation managerial model based on green IT and CSR. International Journal of Computer Science \& Information Technology. 2016; 8(2):51-62.

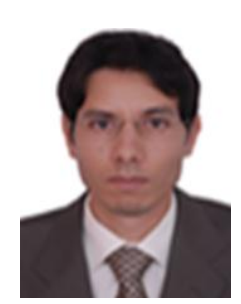

Rachid Hba is a PhD Scholar at the National Higher School of Computer Science and System (ENSIAS), Mohammed V University in Rabat, Morocco. The goal of his research is the reflection on the new generation management models. Rachid got a national computer engineer diploma in 2005, from the ENSIAS Engineering School. Rachid worked as a senior consultant in information and communication technology and project management.

Email: rachid_hba@um5.ac.ma

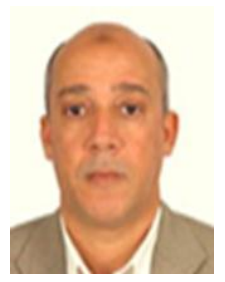

Abdellah El Manouar holds a PhD in economics from Montreal University in 1991, Canada. He is Professor of Higher Education and Head of Business Intelligence Option and IT department and Decision Support. He is a member of the TIME research team at ENSIAS Engineering School (National Higher School of Computer Science and System), Mohammed V University in Rabat, Morocco. His research topics cover finance and investment, management and new economy, financial management and financial engineering.

Email:manouar@ensias.ma 